\title{
The Development of Human Capital as a Factor of Economic Security in the Digital Age
}

\author{
Evgeniya K. Karpunina ${ }^{1, *}$, Ekaterina A. Isaeva ${ }^{2}$, Tatiana V. Abalakina ${ }^{3}$, Irina V. Shilova ${ }^{4}$, Maria A. \\ Kulikova $^{5}$ \\ ${ }^{1}$ Institut of Economics, Management and Service, Tambov State University named after G.R. \\ Derzhavin, Internationalnaya str., 33, Tambov, Russia \\ ${ }^{2}$ Department of Banking, Moscow University for Industry and Finance «Synergy», Izmailovsky val, \\ 2, Moscow, Russia \\ ${ }^{3}$ Department of Corporate Finance and Corporate Governance, Financial University under the \\ Government of the Russian Federation, Leningradsky Prospect, 4, Moscow, Russia \\ ${ }^{4}$ Department of International Economics and foreign economic activity, Voronezh state University, \\ Prospect of Revolution,4a, Voronezh, Russia \\ ${ }^{5}$ Department of Economics, Tambov State Technical University, Academician Ryazanov str, 10A, \\ Tambov, Russia \\ ${ }^{*}$ Corresponding author
}

Keywords: Economic Security, Digital Economy, Human Capital.

Abstract: The new digital age has a turning impact on the way and quality of life of people, the requirements for the implementation of their work functions, the nature of the production processes and the entire global world order. It require the development of human resources as a key factor in the economy, as well as the purposeful management of this development to prepare people for new challenges and ensure economic security and integrity of the state. The purpose of the scientific article is to study the relationship of human capital and economic security of the state, as well as the process of transformation of the identified relationship taking into account the impact of factors of the digital environment.

\section{Introduction}

In the digital age technological progress, increasing fragmentation of production, growing demand for new skills and changing labour relations are becoming an integral part of the labour market. On the one hand, digitalization improves productivity, increases production and creates high-quality jobs, creating new economic and social opportunities in all countries and strengthening their economic security. On the other hand, the introduction of digital technologies can have a destructive impact on productivity, employment and welfare, become a factor in weakening the economic security of the state. Some jobs will soon become obsolete and a large number of vulnerable workers are at risk of unemployment (for example, own-account and unpaid family workers, who already account for 50 per cent of jobs in South-East Asia and the Pacific and 40 per cent in East Asia) [1]. 
In addition, certain industries are also at risk, such as manufacturing. Evidence suggests that the risk of automation may deprive some countries, particularly poorer ones, of economic development opportunities, leading to a new digital divide and increased inequality. This could lead to "premature deindustrialization" in many developing countries before the developed countries reach the industrialization threshold [2]. The human factor increases the impact of information threats to the economic security and integrity of the state, causing the leakage of commercial information, leading to damage to business reputation, uncontrolled use of information sources and, as a result, reduced productivity, failure of accounting and information analysis systems, which increases the vulnerability of companies and creates conditions for direct financial losses.

\section{Materials and Methods}

The research is based on the theory of human capital. One of its first formulations is found in the «Political arithmetic» of W. Petty, where human labor is considered as a factor of economic development, and «the wealth of society depends on the type of employment of people and their abilities to work» [3]. Later, this problem was reflected in the «Study on the nature and causes of the wealth of peoples» by A. Smith: «the welfare of the people is determined mainly by the number of workers and the quality of their skills» [4]. The emergence and formation of the concept of human capital in its modern form became possible thanks to the works of G. Becker. He presented «human capital» as «a set of skills, knowledge and abilities of a person, the cost of which (through education, corporate training, etc.) can bring over time a tangible profit and the employee and his employer» [5]. In later publications, scientists proved that human capital (in individual manifestation) can be revealed as an economic kind of talent, which includes the inherent personal qualities of a person (knowledge, skills, experience, initiatives), tied to his body and available only through his own free will [6].

The identification of the relationship between human capital and factors of economic security of the state (as a qualitative characteristic of the economic system, which determines its ability to maintain normal living conditions of the population, sustainable resources for the development of the national economy, as well as the consistent implementation of national interests) became possible thanks to the research of Senshagov V. [7]. The results of studies of the digital economy conducted by, E. Chang, E. Quaddus, and R. Ramaseshan [8], was used by the authors of this article as a theoretical and methodological framework for the identification of the specificity of human capital management in the digital environment. In addition, the papers of E. Karpunina reveal conceptual issues of economic security in the digital environment [9], which were the basis for the study of this problem.

\section{Results and Discussion}

Our research will be based on the consideration of two key areas.

I ) We will establish the relationship between human capital and the economic security of the state from a systemic perspective.

Security is due to social activities in relation to the state, society and the individual. It occurs during the resolution of contradictions between the objective reality of danger and the need of their prevention, containment and efforts of intelligent beings, social individual, social groups and communities, the subject of activity of which will a particular signs of danger and the specific physical media is a natural social phenomenon. Let us draw attention to the dual nature of security as a category: on the one hand, security is a condition for the existence and further development of the human individual and the communities that he creates; on the other hand, security is the result of activities that lead to the strengthening of the accepted rule of law and the long-term development 
of the state. That is why the structure of economic security can be shared static (associated with the ability to prevent threats and confront them) and dynamic (including aspects of the stability of the system and the provision of development opportunities) components. Economic security, first of all, is characterized by the level of human capital development, the realization of the needs of individuals and society, the presence of developed infrastructure, as well as the nature of integration into the system of world economic relations. In turn, human capital has the ability to reproduce. At the same time, the continuous development of high-efficiency production imposes increasingly stringent requirements to improve the quality of human capital, staffing of production processes.

Human capital can become a source of threats to economic security, and contribute to the sustainable development of the economic system and become a generator for its long-term development. For example, threats and leading risk factors for the economic security of the state in the reproduction and qualitative structuring of the elements of human capital include: the degradation of households as one of the most important areas of human capital formation of future generations; reduction of the inventive activity of scientists and the decline in research activities; the increase in social ill health of the population; underestimation of the importance of the demographic factor in the economic policy of the state; reduction of investment in education and educational degradation of national human capital. This is confirmed by the data from the "World Economic Situation and Prospects 2018» [10], which States that «the structural, long-term forces that contribute to a century-long decline in productivity growth include demographic trends (especially population ageing), a decline in the benefits of the ICT revolution and a slowdown in growth, and the pace of innovation and trade integration [11].

Dabla-Norris, who studies productivity trends from a sector perspective in developed countries, argues that the long-term slowdown in productivity growth reflects two broad factors that include the reallocation of resources to sectors where productivity and growth levels were lower, particularly in services; and the decline in productivity in sectors that account for a growing share of employment, such as social and administrative services. The reasons for weak growth vary from country to country and include both cyclical factors - such as weak demand in developed markets and low commodity prices - and structural factors, including slower trade integration and less dynamic economic transformation. Rodrik attributes this weakness to a widespread lack of industrialization or even premature deindustrialization [12]. Thus, low productivity growth will not only have a negative impact on the medium-term growth prospects, that is, it will become a threat to the economic security of the state, but can seriously undermine progress. Human capital can be considered through the process of preventing negative impacts on the economic security of the country due to the risks and threats associated with human capital and its constituent elements. The purpose of economic security on the part of the social factor is to prevent the irrational use of human capital according to socio-economic, political and national criteria, its redistribution in favor of competing countries.

The formation of an integrated system of economic security of the state requires the appropriate institutional, infrastructure and resource support, integral elements of which are human capital (Fig. 1). 


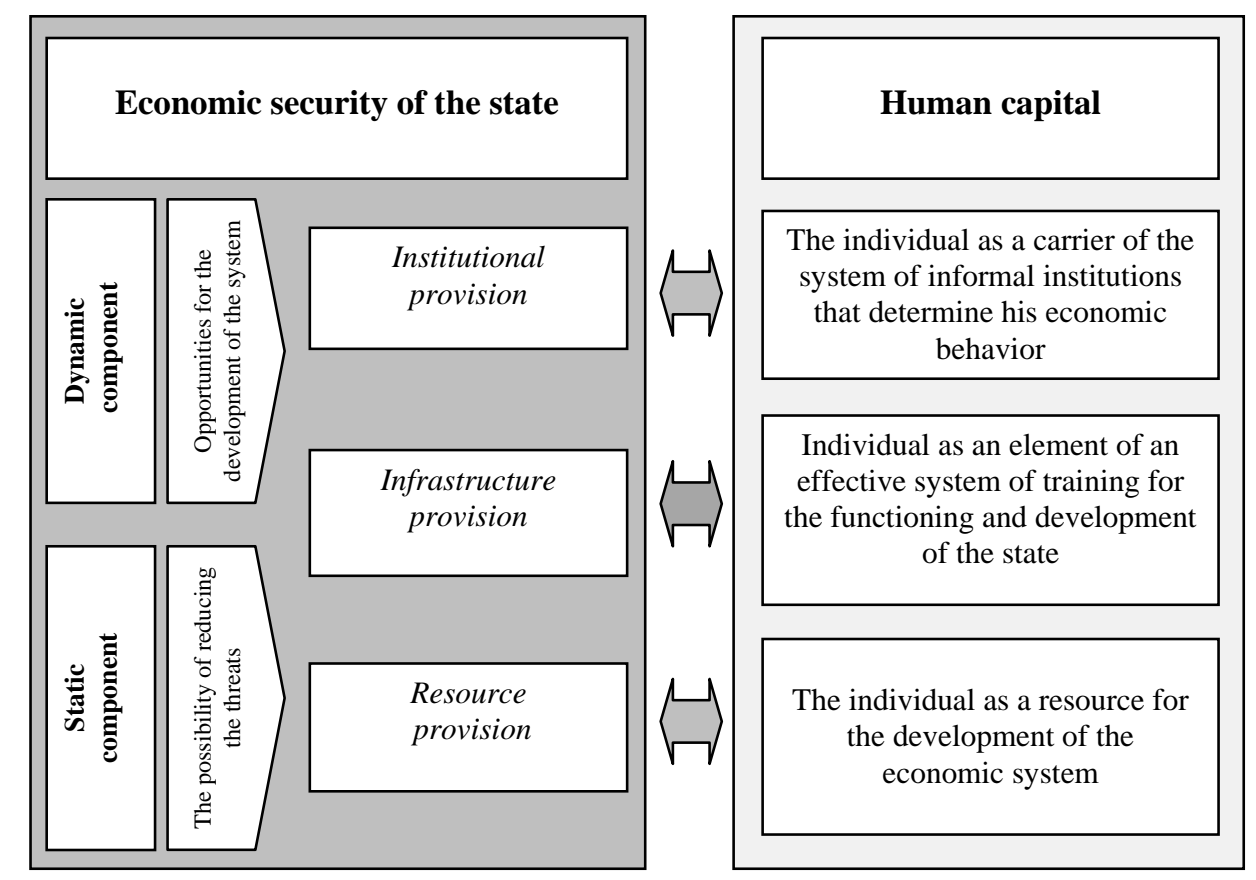

Figure. 1. A Systematic Approach to the Identification of the Relationship between Human Capital and Economic Security of the State

In the structure of the institutional provision of the system of economic security of the state, a special place belongs to the totality of individuals as carriers of the system of informal institutions certain patterns that determine the economic behavior of individuals and the overall strategy of building a life path. An integral element of the infrastructure of the state economic security system is an effective system of education for the economy, which provides its functionality, dynamic stability and development potential. From the point of view of the resource approach, the individual acquires special importance as a carrier of certain knowledge, skills and abilities, which is selfactualized in the economic system as a qualified specialist [13]. The revealed interrelation of human capital and economic security of the state allows us to speak about its comprehensive and crosscutting nature and interdependence of all structural elements of human capital and economic security.

II ) We will look at the transformation of the relationship between human capital development and economic security, taking into account the impact of the digital environment.The digital age dictates its own «rules of the game», transforms the applied business models, makes adjustments to production processes and mechanisms of product promotion. This has an impact on changing the knowledge and skills requirements of staff. New technologies should be applied in business. This requires staff professionalism, adaptability, ease and speed of finding the necessary information, the use of new communication channels with the possibility of being in the access zone. There are new opportunities for modeling scenarios of the situation (forecasting), analysis of the future, optimization of resources, playing scenarios, risk forecasting. The requirements for a significant increase in the speed of response of specialists to the request of the counterparty are formed. Human capital must undergo a huge qualitative transformation in order to be able to play its role (Table 1). 
Table 1. Trends of Digitization and Requirements for Human Capital

\begin{tabular}{|l|l|}
\hline \multicolumn{1}{|c|}{$\begin{array}{c}\text { Elements of } \\
\text { digitalization }\end{array}$} & \multicolumn{1}{c|}{ Human capital requirements } \\
\hline $\begin{array}{l}\text { Information and } \\
\text { communication } \\
\text { technologies }\end{array}$ & $\begin{array}{l}\text { 1) high level and quality of education in the field of information and } \\
\text { communication technologies; 2) information literacy; 3) professionalism in the } \\
\text { field of machine learning and predictive Analytics; 4) competence in the field } \\
\text { of artificial intelligence and robotics; 5) continuous expansion of knowledge in } \\
\text { the field of cybersecurity }\end{array}$ \\
\hline $\begin{array}{l}\text { Organizational } \\
\text { ecosystems } \\
\text { networks }\end{array}$ & $\begin{array}{l}\text { 1) sectoral, professional and geographical mobility; 2) adaptability; 3) analytic; } \\
\text { 4) predictability; 5) continuous education and self-development; 6) high-speed } \\
\text { response }\end{array}$ \\
\hline New nature of work & 1) virtualization; 2) independence; 3) creativity; 4) adaptability; 5) multi-aspect \\
\hline $\begin{array}{l}\text { New competencies } \\
\text { and skills [14] }\end{array}$ & $\begin{array}{l}\text { 1) technical disciplines closely related to specialization (68\%); 2) } \\
\text { communication and team skills (57\%); 3) presentation skills (37\%); 4) time } \\
\text { management (33\%); 5) project management (47\%); 6) sales and negotiation } \\
\text { skills (28\%) }\end{array}$ \\
\hline
\end{tabular}

Doing business requires a constant search for areas in which you can gain a competitive advantage in the market. The condition for improvement is the hiring of competent employees who are able to perform the tasks assigned to them, which are complex and vital for doing business. Companies «compete through people», their success increasingly depends on human capital as well as the organization's ability to manage talent. The experience and skills that form the talent of each of the company's employees require constant improvement in accordance with the pace of development of existing technologies. One of the key tasks to be solved in the process of digitalization of production relations is to provide appropriate personnel. This has a direct impact on economic security in terms of ensuring the sustainability of socio-economic systems. In addition, due to the high level of openness of information systems, universal access to the Internet and widespread automation of production processes, a number of new threats to the economic security of the state are being created [15]. On the one hand, the human factor is a direct source of these threats. On the other hand, the emerging threats are transformed into direct financial losses for companies and the state due to the lack of professionalism of the employee or the delay in his actions to reduce the threats.

\section{Conclusion}

The development of the digital economy depends largely on human capital. Digitalization brings a lot of changes, creates new conditions for the use and development of human capital. Human capital must undergo a qualitative transformation in order to act as a driver of digital and socioeconomic development. As a modern factor of production, it increases the productivity of the economy, stimulates changes in the structure of production and employment, creates new values and attitudes. In the context of digitalization, there is an expansion and strengthening of interdependence of human capital development and the state of economic security of the state. The basis for achieving the state of economic security of the state in the digital environment is to ensure the sufficiency of the expanded reproduction of human capital, while leveling threats from the digital space becomes a key task of the person and the training system formed by him. 


\section{References}

[1]The International Labour Organization 2016. ASEAN in Transformation: How Technology is Changing Jobs and Enterprises? [OL]. https://www.ilo.org/asia/events/WCMS_495244/lang-en/index.htm

[2] D. Rodrik, Premature Deindustrialization [M]. New York: Springer Science+Business Media, 2015.

[3] W. Petty, Economic and statistical works. Vol. I and II [M]. Moscow: Sotsekgiz, 1940.

[4] A. Smith, Study on the nature and causes of the wealth of Nations [M]. Moscow: Sotsekgiz, 1962.

[5] G. Becker, Human capital. Impact on earnings of investments in human capital [J]. USA: EPI, 1993, 11.

[6] K. Noskova, Multilevel system of evaluation of human capital [J]. Economics and innovations management, 2014, 4.

[7] V. Senshagov, Russian economic security. General course: the textbook [C]. Moscow: Business, 2005.

[8] E. Chang, M. Quaddus and R. Ramaseshan, The Vision of DEBI Institute: Digital Ecosystems and Business Intelligence [M]. Perth: DEBII, 2006.

[9] E. Karpunina, E. Yurina, S. Samoylova, Digital Economy and Business Structures: A New Meaning of Interaction or Threat to Economic Security? Proceedings of the 32nd IBIMA, ISBN: 978-0-9998551-1-9, 15-16 November 2018, Seville, Spain.

[10]United Nations. World Economic Situation and Prospects 2018 [J]. Sales No. E.17.II.C.2, 2019.

[11] G. Adler, Gone with the headwinds: Global productivity [J]. IMF Staff Discussion Note, 2017, April.

[12] E. Dabla-Norris, The new normal: A sector-level perspective on productivity trends in advanced economies [J]. IMF Staff Discussion Note, 2015, March.

[13] I. Makarov, I. Pochepaev, The Role of human capital in the system of economic security of the region [J]. Russian entrepreneurship, 2018, 12, vol. 19.

[14]IAB Europe 2018. Human Capital in the Digital Environment. Report 2018 [OL]. https://docviewer.yandex.ru/view/316254058

[15] E. Karpunina, S. Moiseev, O. Gorbunova, Resistance is not hopeless...regarding the policy of countering information threats of economic security. Proceedings of the 33nd IBIMA, ISBN: 978-09998551-2-6, 10-11 April 2019. Granada, Spain. 